\title{
Islamisme, Pos-Islamisme dan Islam Sipil: Membaca Arah Baru Gerakan Islam
}

\author{
Tedi Kholiludin \\ Universitas Wahid Hasyim Semarang \\ Email: tedi_kh@yahoo.com
}

\begin{abstract}
Abstrak
Di ranah kajian Islam, perbedaan antara Islamisme dan Islam sering diabaikan atau bahkan dihilangkan. Namun, demi alasan yang akan menjadi lebih jelas pada penjelasan berikutnya, pembedaan tersebut penting bagi kepercayaan bahwa umat muslim bisa hidup damai dengan non muslim. Keimanan Islam bukanlah penghambat bagi perdamaian atau juga ancaman bagi non muslim lainnya. Di sisi lain, Islamisme menciptakan keretakan peradaban antara muslim dan non-muslim. Bukan hanya label "Yahudi dan tentara Perang Salib" yang dianggap sebagai musuh, tetapi juga menyasar non muslim lainnya: Hindu di Kashmir dan Malaysia, Buddha dan Konfusian di Cina serta Asia Tenggara, orang-orang penganut agama animisme Afrika di Sudan. Islamisme mengklasifikasikan seluruh kalangan non muslim sebagai kuffar (orang-orang kafir) dan dengan demikian berarti merupakan "musuh Islam." Kalangan Muslim liberal pun tidak luput dari sasaran. Selain berkontribusi terhadap polarisasi antara Muslim dan non Muslim lainnya, Islamisme juga memunculkan perseteruan internal yang kejam. Islamisme bukanlah sesuatu yang dibutuhkan oleh peradaban Islam saat ini di tengah krisis yang tengah melandanya. Malahan, kita perlu bersepakat dengan Islam sipil dan liberal terkait perspektif sekular. Dalam melakukan hal tersebut, kita sebagai Muslim non Islamis tidak hanya menerima pluralisme tetapi juga mencari tempat bagi Islam dalam kebinekaan buda'ya dan agama yang membentuk dunia modern. Para muslim liberal bukanlah "suatu irisan kecil". Dengan menggambarkan kita seperti itu, yang akibatnya pun bisa kita abaikan, bukan semata kesalahan faktual, tetapi sebuah langkah taktis, ketika asumsi ini justru cenderung mengalienasikan kalangan muslim non-Islamis sekular yang paling bersahabat dengan Barat.
\end{abstract}

Kata Kunci: Islamisme, Pos-Islamisme, Islam Sipil

\begin{abstract}
In Islamic study, the difference between Islamism and Islamic are often overlooked or even eliminated. However, for clearer reasons will be explained on next chapter. The distinction is important to believe that muslims can live in peace with non-muslims. Islamic faith is not a barrier for peace or even a threat to non-muslims. On the other hand, Islamism creates a rift of civilizations between muslims and non-muslims. Not only label "Jews and Crusaders" were regarded as enemies, but also targeting nonmuslims: Hindus in Kashmir and Malaysia, Buddhist and Confucian in China an Southeast Asia, the African animist religions in Sudan. Islamism classify all nonmuslims as kuffar (infidels) and it means they are all "enemies of moslem." Among the liberal muslims are not missed the target. Beside to contribute the polarization between muslims and non-muslims, Islamism also raises cruel internal conflict. Islamism is not something needed by moslem civilization in the crisis that they faced.
\end{abstract}


Instead, we need to agree that between the civilian moslem and liberal related to secular perspective. In this case, we are as moslem non-Islamism not only accept pluralism but also placing Moslem in cultural diversity and a religion that shape modern world. Liberal Muslims are not "a thin slice". By describing us like that, which its consequent can we ignore, not merely is factual errors, but a tactical step, when assuming it pricely tend to alienate secular Moslem non-Islamist who most friendly to the Western.

\section{Keywords: Islamism, Pos-Islamism, Civil Islamic}

\section{A. Pendahuluan}

Islamisme dan Islam sering diabaikan atau bahkan dihilangkan, namun pembedaan tersebut penting bagi kepercayaan bahwa umat muslim bisa hidup damai dengan non muslim. Keimanan Islam bukanlah penghambat bagi perdamaian atau juga ancaman bagi non muslim lainnya. Di sisi lain, Islamisme menciptakan keretakan peradaban antara muslim dan non-muslim. Bukan hanya label "Yahudi dan tentara Perang Salib" yang dianggap sebagai musuh, tetapi juga menyasar non muslim lainnya: Hindu di Kashmir dan Malaysia, Buddha dan Konfusian di Cina serta Asia Tenggara, orang-orang penganut agama animisme Afrika di Sudan.

Islamisme mengklasifikasikan seluruh kalangan non muslim sebagai kuffar (orang-orang kafir) dan dengan demikian berarti merupakan "musuh Islam." Kalangan muslim liberal pun tidak luput dari sasaran. Selain berkontribusi terhadap polarisasi antara muslim dan non muslim lainnya, Islamisme juga memunculkan perseteruan internal yang kejam. Islamisme bukanlah sesuatu yang dibutuhkan oleh peradaban Islam saat ini di tengah krisis yang tengah melandanya.

Sebagai muslim non Islamis tidak hanya menerima pluralisme tetapi juga mencari tempat bagi Islam dalam kebinekaan budaya dan agama yang membentuk dunia modern. Para muslim liberal bukanlah "suatu irisan kecil". Dengan menggambarkan kita seperti itu, yang akibatnya pun bisa kita abaikan, bukan semata kesalahan faktual, 
tetapi sebuah langkah taktis, ketika asumsi ini justru cenderung mengalienasikan kalangan muslim non-Islamis sekular yang paling bersahabat dengan Barat.

\section{B. Pembahasan}

\section{a. Menulis Ulang Ide Tibi}

Bassam Tibi, salah satu pemikir Islam, mengkritik kecenderungan kelompok yang melakukan politisasi agama. Pikirannya itu termaktub dalam Islam and Islamism. Argumen utamanya langsung dinyatakan di pengantar. Menurut Tibi, Islam sebagai keyakinan dan Islamisme sebagai kategori politik keagamaan adalah dua entitas yang berbeda. Islamisme, kata Tibi, bukanlah bagian dari Islam. Islamisme merupakan tafsir politis atas Islam. Dasar dari Islamisme bukan pada Islam (sebagai keyakinan), tetapi pada penerapan ideologis atas agama di ranah politik. ${ }^{1}$ Buku yang awalnya terbit pada tahun 2012 ini bermaksud untuk menjelaskan perbedaan antara Islam dan Islamisme tersebut.

Islamisme, tidak hanya sekadar masalah politik. Lebih jauh, Islamisme berkaitan dengan politik yang diagamaisasikan (religionized politics) dan oleh Tibbi, model tersebut ditengara sebagai contoh yang paling kuat dari global phenomenon of religious fundamentalism. ${ }^{2}$ "Religionized Politics" adalah model dimana sekelompok masyarakat menawarkan sebuah tatanan politik yang diyakininya sebagai kehendak Allah. Tibi menolak keras model ini. Menurutnya, Islam memang “...menyiratkan nilai-nilai politis tertentu namun tidak mensyaratkan suatu tata pemerintahan khusus."3 Islamisme bisa dikatakan sebagai salah satu bentuk tafsir terhadap Islam, tetapi bukanlah Islam itu sendiri, karena ia adalah sebentuk ideologi politik.

\footnotetext{
${ }^{1}$ Bassam Tibi, Islam dan Islamisme, (Bandung: Mizan, 2016), hlm. 1.

2 Bassam Tibi, Islamism and Islam, (Yale University Press, 2012), hlm. 1.

3 Bassam TIbi, Islam dan Islamisme, hlm. 1.
} 
Tibi mengelaborasi enam ciri utama dengan ideologi Islamisme. Pertama, interpretasi atas Islam sebagai nizam Islami. Dalam pandangan kaum Islamis, Islam adalah din-wa-daulah; agama bersatu dengan negara. Tibi menegaskan bahwa ide dasar yang menjadi pokok dan gagasan utama kelompok Islamis terletak pada keyakinannya tentang kesatuan agama dan negara ini. Ia mengkritik beberapa kecenderungan analis yang melihat Islamisme sebagai semata-mata "Islam Radikal." Padahal jantung dari ideologi Islamisme ini sesungguhnya ada dalam "its quest for political order."4 Jika ide mengenai negara Islam ini belum ditinggalkan, maka orang belum bisa berbicara banyak tentang masyarakat "Pos-Islamisme."5

Kedua, Yahudi sebagai musuh utama yang akan menghancurkan umat Islam. Karena umat Yahudi memiliki cita-cita akan menciptakan "tatanan dunia Yahudi," maka tujuan ini tentu saja akan bertabrakan dengan harapan ideal umat Islam. ${ }^{6}$ Merujuk pada tuturan Hannah Arendt, Tibi membedakan antara Yudeofobia Tradisional yang merupakan kejahatan dan Anti-Semitisme yang adalah kejahatan besar dan mengajurkan genosida. Posisi umat Islam terhadap Yahudi akan membedakan bagaimana Yudeofobia Tradisional dan Anti-Semitisme itu. Kata Tibi, Yudeofobia tidak hanya terjadi dalam masyarakat Jerman atau Eropa, tetapi sepanjang sejarah Islam ada fenomena tersebut. Antisemitisme (dalam pengertian genosida), secara khusus merupakan penyakit Eropa, terutama Jerman, yang tidak pernah ada dalam masyarakat Islam sebelum abad 20. Para nasionalis Arab-Sekuler yang

\footnotetext{
${ }^{4}$ Bassam Tibi, Islamism and Islam, hlm. 32.

5 Gagasan tentang Pos-Islamisme akan dielaborasi di bagian berikut. Perspektif Tibi tentang masyarakat yang masih memimpikan "negara Islam" serta posIslamisme yang berarti kondisi dimana sebuah masyarakat telah menanggalkan ide negara Islam, akan dijadikan sebagai takaran untuk didiskusikan dengan sumbersumber lainnya, terutama karya Asef Bayat.

${ }^{6}$ Bassam Tibi, Islam dan Islamisme, Bab III.
} 
mengadopsinya sekitar tahun 1930 dan "di-Islamisasi" oleh kalangan Islamis kontemporer. Haluan antisemitis kalangan Islamis didasarkan atas dua tema; Islam yang dikepung oleh Yahudi dan tentara salib serta persaingan atas tatanan politik dunia.

Ketiga, demokratisasi dan posisi Islamisme institusional dalam sebuah negara demokratis. ${ }^{7}$ Disini, Tibi menemukan banyak paradoks. Kaum Islamis pada dasarnya menghendaki mendirikan negara Islam, yang tentunya akan bertentangan dengan misi demokratisasi yang didalamnya terkandung gagasan civic pluralism. Meski begitu, demokrasi harus membuka ruang bagi kelompok dengan pelbagai suara, termasuk mereka yang menyeru gagasan negara Islam. Terhadap situasi ini, ada dua pendekatan yang bisa digunakan; inklusioner seperti di Turki atau eksklusioner laiknya yang terjadi di Aljazair.

Keempat, evolusi jihad tradisional menuju jihadisme. ${ }^{8}$ Kata Tibi, salah satu karakter dari kelompok Islamis adalah ideologi jihadisme yang merupakan reinterpretasi dari jihad. Jihadisme merupakan "terror di pikiran Tuhan" (istilah yang dipinjam Tibi dari Mark Juergensmeyer). Fakta sekaligus metode yang dipraktikkan tidak dapat dipisahkan dari legitimasinaya sebagai "holy terror."

Kelima, syariatisasi negara. ${ }^{9}$ Di bawah bendera Islamisme, kata Tibbi, “...classical shari'a has been developed into the idea of shari'atization of the state."10 Kalangan Islamisme menafsirkan teks alQur'an untuk mendukung ide politik yang telah direligionisasi. Untuk mengatasi ekpektasi kelompok Islamis ini, Tibi mengusulkan fleksibilitas yang akan memperkaya hukum Islam itu sendiri. Ia

\footnotetext{
${ }^{7}$ Bassam Tibi, Islam dan Islamisme, Bab IV.

${ }^{8}$ Bassam Tibi, Islam dan Islamisme, Bab V.

${ }^{9}$ Bassam Tibi, Islam dan Islamisme, Bab VI.

${ }^{10}$ Bassam Tibi, Islamism and Islam, hlm. 175.
} 
menawarkan pembatasan syariat pada etika agama, sehingga syariat tidak betul-betul ditinggalkan.

Keenam, kelompok Islamis sangat terobsesi untuk mengajukan soal kemurnian sebagai klaim atas autentisitas. ${ }^{11}$ Klaim ini yang nanti akan menentukan posisi Islamis terhadap sekularisasi dan desekularisasi. Argumen utama yang ingin diajukan Tibi adalah "krisis Islam modern diperburuk oleh kesulitan menghadapi modernitas dan juga oleh krisis pembangunan yang terkait dengan modernisasi dunia Arab yang tak berhasil." Kesengsaraan ini yang dalam pandangan kelompok Islami disebabkan oleh Barat. Jawaban untuk segala krisis adalah kembali pada akar; Yang Suci.

Terhadap gerakan (Islamisme) yang tumbuh di pelbagai belahan dunia, Tibi menyimpulkan, fenomena itu "bukanlah warisan Islam tetapi merupakan interpretasi politik kontemporer atas Islam yang didasarkan pada penciptaan tradisi."12 Meski Islamisme itu bukan Islam, tapi Islamisme tidaklah berdiri di luar Islam. Di bagian akhir buku "Islam and Islamism," Menurut Tibi, ulasan Scott Appleby dalam "The Ambivalence of the Sacred," tentang posisi agama yang dipolitisasi, tidak dicermatinya sebagai sebuah perangkap. ${ }^{13}$ Bagi Tibi, solusi konflik haruslah sekuler, agar bisa diterima semua pihak. Tibi berharap bahwa Islam sipil akan menjadi alternatif dari merebaknya gagasan Islamisme. ${ }^{14}$

\section{b. Islamisme dan Pos-Islamisme: Dialog Bayat dan Tibi}

\footnotetext{
11 Bassam Tibi, Islam dan Islamisme, Bab VII.

12 Bassam Tibi, Islam dan Islamisme, hlm. 302.

13 Bassam Tibi, Islam dan Islamisme, hlm. 308. Scott Appleby, The Ambivalence of the Sacred: religion, Violence, and Reconciliation, (Lanham, Md.: Rowman and Littlefi eld, 2000).

${ }^{14}$ Bassam Tibi, Islam dan Islamisme, Bab VIII.
} 
Pada tahun 2007, Asef Bayat, Profesor Sosiologi di Illionis University kelahiran Iran, menulis "Making Islam Democratic: Social Movement and Post-Islamist Turn."15 Ia kemudian mengenalkan istilah Pos-Islamisme. Gagasan tentang Pos-Islamis itu sendiri, kata Bayat, telah ia kenalkan pada tahun 1996 melalui sebuah esai pendek, "The Coming of a Post-Islamist Society." Dalam tulisan itu, Bayat mendefinisikan Pos-Islamisme sebagai “...a condition where, following a phase of experimentation, the appeal, energy, symbols and sources of legitimacy of Islamism get exhausted, even among its once-ardent supporters. As such, post-Islamism is not anti-Islamic, but rather reflects a tendency to resecularize religion. Predominantly, it is marked by a call to limit the political role of religion."16

Dalam kasus Iran kontemporer, Bayat melanjutkan, PosIslamisme dinyatakan dalam gagasan fusi antara Islam (sebagai iman pribadi) dan kebebasan serta pilihan individu; dan Pos-Islamisme dikaitkan dengan nilai-nilai demokrasi dan aspek modernitas. Ide yang ingin diusung adalah bahwa Islam tidak memiliki jawaban untuk seluruh masalah sosial, politik, dan ekonomi masyarakat. ${ }^{17}$ Dengan

15 Buku ini diterjemahkan ke dalam bahasa Indonesia, Asef Bayat, Pos-Islamisme, (Yogyakarta: LKiS, 2011).

16 Asef Bayat, "The Coming of a Post-Islamist Society," Critique, Fall, 1996, 45-46.

17 Bayat menyebut Abdolkarim Soroush sebagai intelektual penting yang mewarnai gerakan Pos-Islamisme. Dalam sebuah Untuk memenuhi tuntutan tersebut, maka Soroush menawarkan tiga gagasan yang ia tuangkan dalam paper singkatnya, "Rationalist Traditions in Islam" yang ia presentasikan di Heidelberg tahun 2004. Soroush mengatakan bahwa ada tiga ide yang harus dikembangkan untuk untuk mendamaikan agama dan modernitas, termasuk untuk mewujudkan harmonisasi umat beragma. Pertama, ide minimalis agama (minimalist idea of religion). Kedua, ide ekstra religius (extra-religious idea). Upaya ketiga yang harus diwujudkan adalah ide tentang hak-hak (the idea of rights) dalam beragama. Pengembangan bahasa hak (language of rights) ini menjadi sangat penting, karena dalam banyak agama bahasa yang sering diajukan adalah bahasa kewajiban. Lihat Abdolkarim Soroush, "Rationalist Traditions in Islam," makalah pada International Conference Islam-Religion and Democracy, Heidelberg Jerman, 2004. Untuk memahami pemikiran Soroush bisa lihat dalam Abdolkarim Soroush, Reason, Freedom And 
kata lain, kata Bayat, Pos-Islamisme bukan hanya Islam kompatibel dengan modernitas, tetapi kelangsungan hidup sebuah agama sangat tergantung pada pencapaian kompatibilitas ini. Bayat memberikan ilustrasi tentang sikap seorang Pos-Islamis dalam sebuah ungkapan, "kami tidak keberatan jika masjid dihancurkan untuk membuat jalan raya." 18

Bayat menjelaskan mengenai fase di mana Pos-Islamisme itu hadir. Pada fase eksperimentasi, seruan, energi dan sumber-sumber legitimasi Islamisme terkuras habis, bahkan dari kalangan para pendukung yang sangat ambisius. ${ }^{19}$ Mereka sadar akan keganjilan dan ketidaksempurnaan sistem yang dimiliki ketika akan dijadikan sebagai institusi pemerintahan. Situasi ini membuat mereka ada dalam kondisi rawan kritik. Maka jalan yang dipilih adalah upaya pragmatis agar sistem bisa dipertahankan, meski kemudian meninggalkan prinsip dasarnya. ${ }^{20}$

Secara sadar, Pos-Islamisme juga dimaksudkan untuk secara strategis membatasi gerak Islamisme, baik secara sosial, politik maupun intelektual. Pos-Islamisme adalah upaya untuk meleburkan keagamaan dan hak, iman dan pembebasan, Islam dan kebebasan. ${ }^{21}$ Penekanannya adalah pada hak daripada tugas dan kewajiban, menjunjung pluralitas menegaskan kesejarahan kitab suci dan selalu berorientasi pada masa depan. Jika Islamisme digambarkan sebagai

Democracy in Islam: Essential Writings of Abdolkarim Soroush, (New York: Oxford University Press, 2000). Buku ini sudah diterjemahkan ke Bahasa Indonesia Abdolkarim Soroush, Menggugat Otoritas Tradisi dan Agama, (Bandung: Mizan, 2002).

18 Bayat mengutip kata-kata ini dari salah seorang diplomat luar negeri Iran di tahun 1995 yang namanya tidak ia sebutkan. Asef Bayat, "The Coming of a PostIslamist Society," Critique, Fall, 1996, 46.

${ }^{19}$ Asef Bayat, Pos-Islamisme, (Yogyakarta: LKiS, 2011), hlm. 19.

20 Ibid.

${ }^{21}$ Ibid., hlm. 20. 
peleburan agama dan tanggungjawab, Pos-Islamisme menekankan sikap keberagamaan dan Hak Asasi Manusia (HAM). ${ }^{22}$

Sebagai sebuah kondisi, proyek, maupun gerakan, ada tiga alasan yang membuat pos-Islamisme ini bisa terjadi. ${ }^{23}$ Pertama, kegagalan dan pro-kontra proyek Islamisme memerlukan komitmen pemikiran Islamisme dari dalam. Kedua, perubahan sosial yang ditandai dengan urbaniasi, perubahan ekonomi dan meningkatnya angka melek huruf. Situasi ini akan membangkitkan para aktor untuk mendesakkan transformasi sosial dan politik. Ketiga, konteks perubahan-perubahan global yang terjadi.

Dalam "Islamism and Islam," Tibi mempertanyakan mereka yang berbicara Pos-Islamisme. Bagi Tibi, percakapan tentang sebuah PosIslamisme hanya mungkin bisa dilakukan ketika seorang Islamis meninggalkan ideologi Islamismenya. Dan ketika itu dilakukan, maka ia bukan lagi Islamis dan bahkan mungkin menjadi muslim liberal. Tibi tidak percaya adanya kelompok "Islamisme demorkratis," karena yang mungkin ada barangkali adalah "totalitarianisme demokratis." ${ }^{24}$ Ide Pos-Islamisme, terang Tibi, dalam beberapa hal kerap disalahpahami. Salah satunya adalah kasus ketika menurunnya pengaruh salah satu cabang jihad Islamisme terhadap Islamisme institusional.

Tibi tidak merujuk pada karya Bayat ketika ia mengelaborasi dinamika pos-Islamisme. Tibi juga tidak berupaya mendefinisikan secara konseptual tentang apa itu Pos-Islamisme. Namun, ia memetakan prinsip dasar dari Pos-Islamisme yang hanya mungkin bisa didiskusikan ketika kelompok Islamisme menanggalkan prinsip dasarnya untuk mendirikan negara Islam. Di sini, gagasan dasar Tibi,

\footnotetext{
22 Ibid.

${ }^{23}$ Ibid., hlm. 180.

${ }^{24}$ Bassam Tibi, Islam dan Islamisme, hlm. 277.
} 
sejatinya tak terlampau jauh dari maksud Pos-Islamisme yang dicermati Tibi.

Meski begitu, membaca Tibi dengan kacamata Bayat membuat jelas posisi Tibi yang sesungguhnya terlampau men-generalisasi situasi di Timur Tengah. Dalam pandangan Tibi secara umum, kekuatan Islamisme di Iran semata untuk memberikan stabilitas dalam konteks totaliter. Bahkan represi ditingkatkan untuk mempertahankan kekuasaan melalui pemilihan umum secara formal. ${ }^{25}$ Disinilah Tibi berbeda dengan Bayat dalam mendudukkan Iran. Bayat lebih melihat fenomena Iran (terutama tahun 1990-an) sebagai kondisi dimana gerakan Pos-Islamisme berkembang. ${ }^{26}$ Para intelektual, pemuda, perempuan, kelas professional, mengusung visi baru tentang masyarakat dan pemerintah yang diekspresikan dalam pemandangan baru terhadap ruang publik, budaya pemuda, politik mahasiswa, hubungan gender, negara dan pemikiran agama. Bayat menyoroti dinamika Pos-Islamisme dari aktivisme yang dilakukan oleh kelompok-kelompok tersebut yang justru menunjukkan "dinamika lain" di Iran.

\section{c. Islam Sipil di Indonesia: Prospek dan Tantangan}

Berbarengan dengan kritiknya terhadap Islamisme, Tibi berharap pada model "civil Islam" atau Islam sipil. Ia kemudian menyebut Indonesia sebagai salah satu negara yang memiliki tradisi Islam sipil, tetapi tidak pernah mampu memengaruhi pemikiran di dunia Arab. Islam sipil di Indonesia sekaligus membantah anggapan umum bahwa Islam dan demokrasi itu bertemu di Eropa. ${ }^{27}$

\footnotetext{
${ }_{25}$ Bassam Tibi, Islam dan Islamisme, hlm. 31.

${ }^{26}$ Asef Bayat, Pos-Islamisme, Bab III (Terbentuknya Gerakan Pos-Islamisme).

27 Bassam Tibi, Islam dan Islamisme, hlm. 139.
} 
Robert Hefner telah melakukan pekerjaan yang baik untuk mengelaborasi Civil Islam di Indonesia. ${ }^{28}$ Hefner mengatakan, "Sembari mengafirmasi legitimasi agama dalam kehidupan publik, Islam sipil menolak khayalan negara Islam dengan mengakui bahwa formula untuk memfusikan otoritas agama dan negara ini mmengabaikan pelajaran dari sejarah Islam itu sendiri."29 Demokrasi, kata Hefner tidak akan bisa berjalan melalui masyarakat sipil dan budaya kewargaan saja. "Masyarakat sipil yang sehat mensyaratkan negara yang beradab." Di Indonesia, negara model demikian akan bisa bekerja dengan kebesaran warga serta humanitarianisme Islam sipil. ${ }^{30}$

Ditilik dari sisi geografis, Indonesia boleh dikatakan sebagai "wilayah pinggir" dalam peta Islam dengan merujuk pada Timur Tengah sebagai porosnya. ${ }^{31}$ Keberadaannya di pinggir kerap mencandera masyarakat muslim Indonesia dengan klaim-klaim konotatif; sinkretik, "tidak sempurna," inferior, dan lain-lain. Meski demikian, optimisme mengenai kebangkitan Islam, justru hadir dari bagian pinggir ini. Ketika berkunjung ke Indonesia pada tahun 1985, Fazlur Rahman seorang Intelektual asal Pakistan menegaskan kalau harapan tentang kemajuan dan pembaharuan tradisi pemikiran Islam ada di dua negara; Turki dan Indonesia.

Fleksibilitas dalam memaknai ajaran Islam juga menjadi alasan lain mengapa Indonesia patut dipertimbangkan. Pergumulan Islam dengan tradisi menghadirkan sebuah manifesto keberislaman yang

\footnotetext{
${ }^{28}$ Meski data yang dielaborasi Hefner ketika memperkenalkan gagasan Islam sipil sangatlah memadai, tetapi bangunan teoritik tentang "Civil Islam" sendiri agak terabaikan.

29 Robert W. Hefner, Civil Islam: Islam dan Demokratisasi di Indonesia, (Jakarta: ISAI, 2001), hlm. 46.

${ }^{30}$ Ibid.

31 Bagian ini hingga akhir tulisan, saya kutip utuh dari Tedi Kholiludin, "Multiwajah Islam," dalam http://elsaonline.com/?p=5069. Dibuka 28 September 2016.
} 
adatif dan moderat. Rahman mengatakan bahwa Pancasila, sebagai pilar bangsa Indonesia merupakan tafsiran bangsa Indonesia terhadap Islam yang sudah disesuaikan dengan kondisi masyarakat dan budayanya (via Bruinessen, 2011). Dekade 90-an, Indonesia panen intelektual progresif. Situasi ini semakin menggenapi prasyarat kebangkitan tradisi intelektual muslim tersebut.

Optimisme terhadap kebangkitan pemikiran Islam Indonesia seperti yang dilontarkan Fazlur Rahman (juga Nasr Hamid Abu Zayd), tentu bukannya tanpa tantangan. Akhir-akhir ini, gejala uniformitas Islam begitu sangat kuat terasa. Meski masih belum menjadi arus utama, tetapi kehadirannya potensial menggoyang pertahanan kultural bangsa Indonesia. Pasca reformasi kecenderungan untuk menjadikan Islam sebagai ideologi politik begitu kentara. Ini adalah tantangan besar yang potensial mereduksi Islam yang sesungguhnya multiwajah itu.

\section{Simpulan}

Islamisme pada dasarnya bukan warisan Islam tetapi merupakan interpretasi politik kontemporer atas Islam yang didasarkan pada penciptaan tradisi. Adapun sebuah Pos-Islamisme hanya mungkin bisa dilakukan ketika seorang Islamis meninggalkan ideologi Islamismenya. Dan ketika itu dilakukan, maka ia bukan lagi Islamis dan bahkan mungkin menjadi muslim liberal. Berbarengan dengan kritiknya terhadap Islamisme, Tibi berharap pada model "civil Islam" atau Islam sipil. Islam sipil menolak khayalan negara Islam dengan mengakui bahwa formula untuk memfusikan otoritas agama dan negara ini mengabaikan pelajaran dari sejarah Islam itu. 
Appleby, Scott, The Ambivalence of the Sacred: religion, Violence, and Reconciliation, Lanham, Md.: Rowman and Littlefi eld, 2000.

Bayat, Asef, “The Coming of a Post-Islamist Society," Critique, Fall, 1996. Pos-Islamisme, Yogyakarta: LKiS, 2011.

Hefner, Robert W., Civil Islam: Islam dan Demokratisasi di Indonesia, Jakarta: ISAI, 2001.

Kholiludin, Tedi, "Multi wajah Islam," dalam http://elsaonline.com/?p=5069. Diakses 28 September 2016.

Soroush, Abdolkarim, "Rationalist Traditions in Islam," makalah pada International Conference Islam-Religion and Democracy, Heidelberg Jerman, 2004.

Mizan, 2002.

Menggugat Otoritas Tradisi dan Agama, Bandung:

Reason, Freedom And Democracy in Islam: Essential Writings of Abdolkarim Soroush, New York: Oxford University Press, 2000.

Tibi, Bassam, Islam dan Islamisme, Bandung: Mizan, 2016. Islamism and Islam, Yale University Press, 2012. 